\title{
LAND USE CHANGES IN THE LAST HALF CENTURY AND THEIR IMPACT ON WATER RETENTION IN THE SUMAVA MOUNTAINS AND FOOTHILLS (CZECH REPUBLIC)
}

Václav Bystřický, Jana Moravcová, Jakub Polenský, Jiří Pečenka ${ }^{1}$

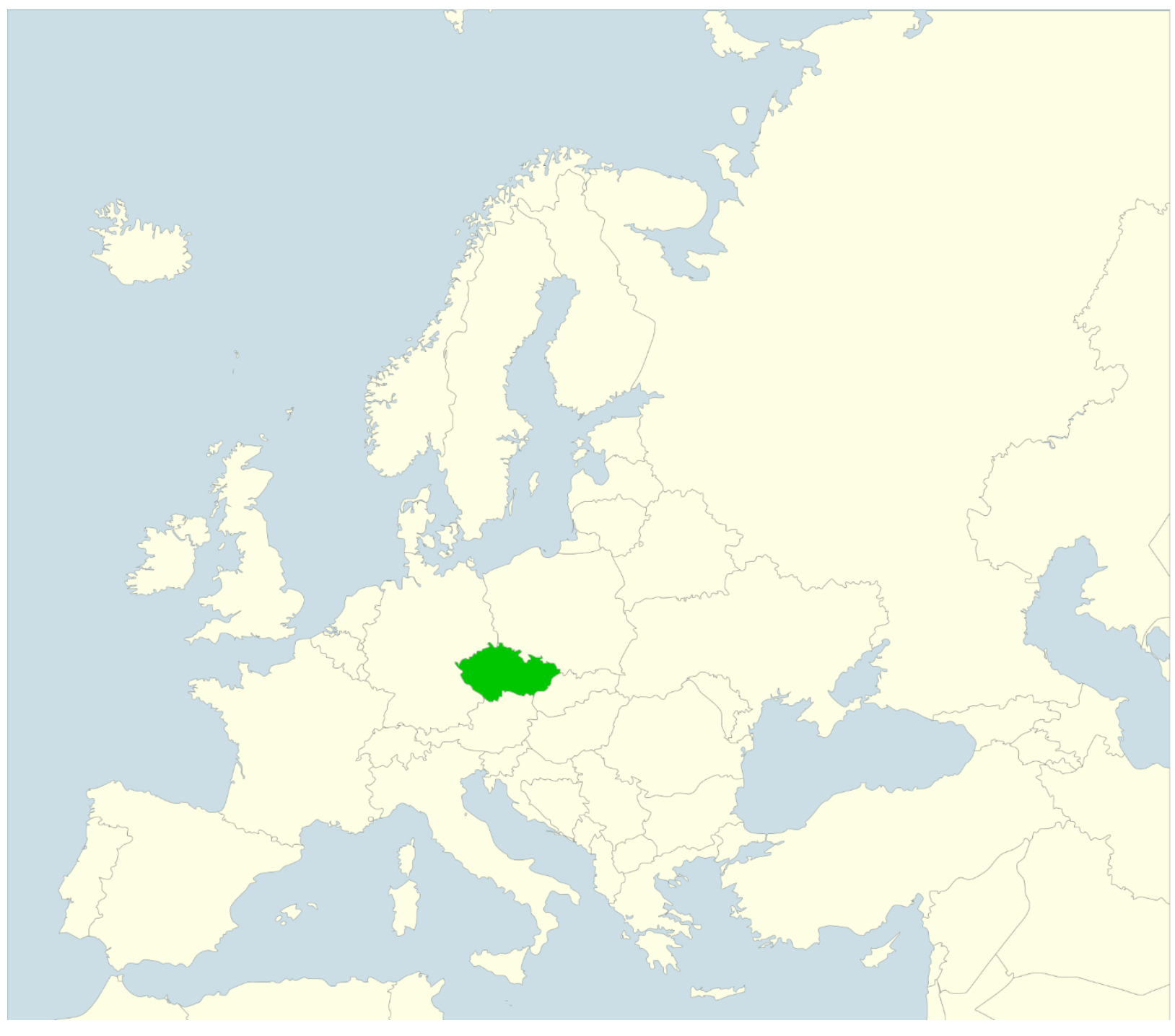

${ }^{1}$ Ing. Václav Bystřický, Ph.D., Ing. Jana Moravcová, Ph.D., Ing. Jakub Polenský, Ing. Jiří Pečenka, Department of Landscape Management, Agricultural Faculty, University of South Bohemia, Studentská 13, 37005 Ceske Budejovice, Czech Republic; e-mails: bystric@zf.jcu.cz; moravj04@zf.jcu.cz; Jakub.polensky@seznam.cz; pecenka.jiri@email.cz 
Abstract: Changes in land use and runoff characteristics in Otava river basin and its two subcatchment (Volšovka and Vydra) were examined. The goal was to find out how water retention have responded to changes in landscape management in Šumava mountains and foothills since the year 1970. There were two basic levels of changing land use - (a) conversion of arable land with varying intensity at different management of intensive and extensive grassland, (b) deforestation of large areas of indigenous mostly spruce monocultures and their transfer to the shrub and herbaceous vegetation covering the surface with a discontinuous vegetation. Water retention in Sumava mountains is locally reduced due to vulnerability of monoculture spruce forests by natural disasters (windstorms), diseases and pests. A positive effect of current agricultural management in the Šumava foothills on the reduction of direct runoff during intense rainfall was confirmed.

Key words: land use, water retention, direct runoff, runoff CN, Šumava

Abstrakt: Článek řeší změnu využití území a odtokových charakteristik v povodí řeky Otavy a jeho dvou subpovodích (povodí řeky Volšovky a Vydry). Cílem práce bylo zjistit, jak se změnila retence vody $v$ krajině společně se změnou využití území $v$ horských partiích a podhưří Šumavy od roku 1970. Změna využití území probíhala dvěma hlavními směry - (a) Převod orné půdy s různou intenzitou hospodaření na různě intenzivní či extenzivní louky a pastviny, (b) Odlesňování rozsáhlých ploch původních většinou smrkových monokultur a jejich převod na křovinatou a bylinnou vegetaci s nesouvislým pokryvem povrchu. V horských polohách Šumavy je retence vody místy snižována $\mathrm{v}$ důsledku zranitelnosti smrkových monokulturních lesů prírodními katastrofami (vichřice), nemocemi a škůdci. V podhůří Šumavy byl prokázán pozitivní vliv současného managementu krajiny na snižování přímého odtoku při intenzivních srážkách.

\section{Introduction}

Precipitation and its amount is the main driver of hydrological processes in the catchment. Its dissemination is dependent on environmental conditions, so it is very important to notice changes in land cover, as one of the most important factors affecting runoff from the catchment. This factor has special importance in mountain areas, which are characterized by longer, more frequent and more plentiful rainfall events throughout the year. Along with climate change causing extreme weather events that leads to a greater susceptibility of mountain regions to extreme events such as floods or droughts. Sudden increase in the level of mountain rivers, then usually leads to flooding in areas of the highlands and lowlands (Romanowicz et al., 2012).

Land cover mainly determines the hydrological transformation of rainfall in the catchment. Tesaŕ et al. (2004) also dealt with vegetation cover and its changes impact on water regime of soils in upper parts of streams catchment. By measuring soil moisture, they demonstrated that soil water regime in these areas completely covered by vegetation in wet conditions is not dependent on the composition of vegetation, while in dry periods is significantly influenced by its composition. This is also reflected on the water regime, which is independent of species composition of plant cover where the surface vegetation remains unchanged. Now land use changes have a major impact on the change of hydrological processes at local, regional and global scale. Scaling issues (observations regarding the different scale) are dealing for example with the impact of long-term changes in land use on the hydrological and ecological processes in the landscape on three hierarchy level: subcatchment, catchment and river watershed. Nejadhashemi, Wardynski and Munoz (2011) also dealt with the problematics of scaling issues. Changes over large areas may cause short (rapid surface runoff) or long (changes in specific or basic runoff) changes in 
response basin, increasing the risk of extreme flows and the consequent threat of flood or prolonged decline in groundwater levels (Bhaduri et al., 2000)

Farmland has the most significant impact on the components of the water balance, especially surface runoff. It is because after harvest and shortly after planting soil is not protected against impact of raindrops and thereby water is rapidly flowing out of the catchment.

On the other hand, forests significantly increase retention of precipitation (precipitation detention in a forest ecosystem) thus reducing the size of effective rainfall and contribute to the retardation (delay) of runoff. Retention capacity compared to other types of environments (e.g. meadows, fields) is significantly higher (Bíba, 2010). Infiltration is in this process the decisive factor. Badoux et al. (2006) in their study confirmed the assumption of higher long-term runoff in areas with damaged forests due to storms, in addition to the power of the secondary drainage channels. A special type of land cover can be peatlands. There was also demonstrated the ambivalence of flow in rivers fed from peatlands. When filling the upland moor at full capacity, there is a rapid rise in outflows, while during periods of drought peatlands don't feed watercourses.

\section{Material}

\subsection{Study area}

Otava river, its upper reaches to the town of Sušice and its two subcatchments Volšovka and Vydra were selected to demonstrate the impact of land use changes in the last half century on runoff characteristics (see Fig. 1).

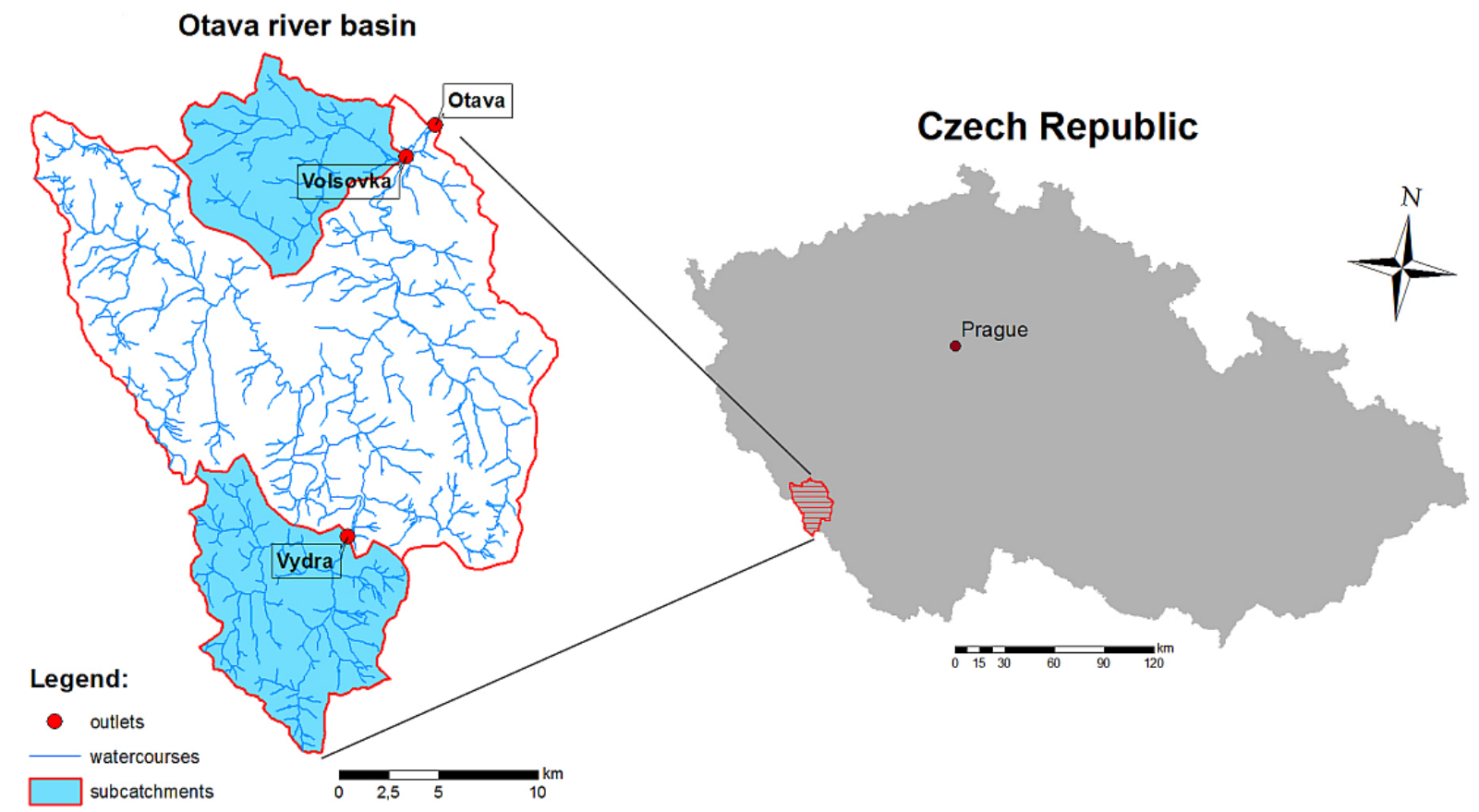

Fig 1. Overview map of the investigated river basin (Otava) and its subcatchments (Volšovka and Vydra).

This area has been long inhabited and used for many different aspects of human activity. The study will cover the changes that have occurred in the area last half century (the river basin management was practically unchanged till the mid- $19^{\text {th }}$ century).

Otava river springs in the Pilsen region in the southwest of the Czech Republic. It is a left tributary of the VItava river originates at the confluence of smaller watercourses Vydra and Křemelná at Čeňkova sawmill in Šumava mountains. The entire basin of water flow consists of many subbasins of natural waterways and one man-made shipping channel.

Otava river basin is quite rugged. Especially the southern part of the area is predominantly mountainous. Geographically it falls into the area of the Šumava mountains and foothills, with 
an average altitude of 1,003 meters above sea level. Watershed average slope is $6.5^{\circ} \pm 4.3^{\circ}$ (SD).

From a geological point of view metamorphic rocks (gneisses and migmatite) and magmatic Moldanubic rocks (granite and granodiorite) dominate. The magmatic types of rock are mainly in the top parts of the mountains. Peat bogs also occurred frequently in the uppermost part of the river basin. Sand and gravel are then located mainly around watercourses. In the flatter, northern part of the river basin there are also disseminated limestone and erlan islands.

From the pedological point of view podsols completely dominate in the forests. Cambisols, stagnosols and in permanently wet areas with high ground water gleysols occur mostly on agricultural lands. Modal fluvisols are developed around watercourses. Mainly in the northern half of the river basin small patches of leptosols are located.

From the climatic point of view the Otava river basin falls mostly in cold climatic area with longterm average annual air temperature of $3.7^{\circ} \mathrm{C}$ (average temperature in January $-4.4^{\circ} \mathrm{C}$ and an average July temperature of $12.5^{\circ} \mathrm{C}$ ). The northern plains of the basin are in the temperate climatic zone, characterized by an average annual temperature of $7.2{ }^{\circ} \mathrm{C}$ (average temperature in January $-2.5^{\circ} \mathrm{C}$ and an average July temperature of $17.0^{\circ} \mathrm{C}$ ). Rainfall totals are very diverse with long-term average annual value for mountain areas $1486 \mathrm{~mm}$ and for the flat part $631 \mathrm{~mm}$.

\subsection{Hydrology description}

Area of the Otava river basin (outlet in the town Sušice) is $517.3 \mathrm{~km}^{2}$. The first of two parts, of which the Otava river is composed, Vydra is created by the confluence of three rivers in the mountain village Modrava at an altitude of $978 \mathrm{~m}$ above sea level. The second watercourse from which the Otava river is formed, is Křemelná river, which rises at an altitude of 1050-1170 $\mathrm{m}$ above sea level. Compared to Vydra river Křemelná river is leisurely, meandering watercourse. After the confluence of Křemelná and Vydra at an altitude of $627 \mathrm{~m}$ above sea level at Čeňkova sawmill continues the stream as the Otava river.

The first selected subcatchment of the Otava river basin in this paper is upper part of Vydra river basin - outlet is just before the beginning of artificially built Vchynicko - Tetovský floating channel (at an altitude of $937 \mathrm{~m}$ above sea level surpassed water from the Vydra River by original $14 \mathrm{~km}$ long route and $255 \mathrm{~m}$ elevation to the Křemelná river at an altitude of $682 \mathrm{~m}$ above sea level). Area of this subcatchment is $89.5 \mathrm{~km}^{2}$.

The second selected subcatchment of the Otava river basin in this paper is Volšovka river basin - outlet is just before the confluence with Otava river (slightly above Sušice town). Area of this subcatchment is $73.2 \mathrm{~km}^{2}$.

\section{Methods}

\subsection{Land use}

To categorize land use the results of Corine Land Cover project were used, for the years 1970, 1990, 2000, 2006 and 2012. The CORINE Land Cover (CLC) inventory was initiated in 1970. Updates have been produced in 1990, 2000, 2006, and 2012. It consists of an inventory of land cover in 44 classes. CLC uses a Minimum Mapping Unit of 25 hectares (ha) for areal phenomena and a minimum width of $100 \mathrm{~m}$ for linear phenomena. The time series are complemented by change layers, which highlight changes in land cover with the minimum mapping unit of 5 ha.

\subsection{Direct runoff}

To quantify changes in direct runoff height in a different river basin management (i.e. different land use) under the same designed rainfall events $\mathrm{CN}$ curve number method was used, because in the Czech Republic and abroad, this method is often used, among other things, for assessing the impact of changes in land use on the size of the direct runoff (Kašpárek and Peláková, 2014).

The runoff curve number (also called a curve number or simply $\mathrm{CN}$ ) is an empirical parameter used in hydrology for predicting direct runoff or infiltration from rainfall excess. The curve number 
method was developed by the USDA Natural Resources Conservation Service, which was formerly called the Soil Conservation Service or SCS. The runoff curve number was developed from an empirical analysis of runoff from small catchments and hillslope plots monitored by the USDA. It is widely used and is an efficient method for determining the approximate amount of direct runoff from a rainfall event in the area.

The basic input to $C N$ method is designed rainfall event $(P-[\mathrm{mm}])$ assuming uniform distribution over the entire river basin area. For rainfall-runoff event for a given time is assumed that the ratio between the current retention ( $\mathrm{F}-[\mathrm{mm}])$ and maximum potential retention of the basin $(\mathrm{S}-[\mathrm{mm}])$ is the same as the ratio between the direct runoff $(Q-[\mathrm{mm}])$ and the rainfall without initial abstraction (P - la - [mm]). Initial abstraction is expected to be 0,2.S (Janeček and Kovář, 2010). Using balance equations were derived from these assumptions following equation:

$$
Q=\frac{P-0,2 \times S}{P+0,8 \times S}, \text { where } P \geq 0,2 \times S
$$

Described method uses runoff curve numbers $(\mathrm{CN})$ that transform the retention, instead of potential retention, so that the $\mathrm{CN}$ ranges from 0 to 100 . Transformation for the variable in $\mathrm{mm}$ is following:

$$
C N=\frac{25400}{S+254}
$$

Runoff curve numbers are according Janeček (2002) determined by:

- hydrologic soil groups (HSG) divided into four groups A, B, C, D according to the minimum infiltration rates of soils without vegetation cover when thoroughly wetted,

- soil moisture at the beginning of the event,

- land use, i.e. the type of vegetation cover, tillage and application of erosion control methods.

To categorize the soils into the HSG (hydrologic soil groups) were used method described in Šercl (2006), which adapts the CN method for steeper area. When categorizing soil into HSG were therefore considered not only the infiltration capacity of soils, but also the water retention capacity of the soils and the slope of the territory derived from the digital terrain model. Everything was calculated in software ArcGIS 10.1 in raster format. Data of the infiltration rates and water retention capacities were taken from the "Research Institute for Soil and Water Conservation" in Prague, digital terrain model was constructed in ArcGIS 10.1 based on the contours of the model ZABAGED (The geographic base data of the Czech Republic from the "Czech Office for Surveying, Mapping and Cadastre").

For each combination of different HSG categorizations (by infiltration capacity, water retention capacity and the slope of territory) with land use (used GIS tool "Raster Calculator") were subsequently determined values of CN (tool "Reclassify") and subsequently from these (three) $\mathrm{CN}$ values (raster) the mean for each pixel (tool "Cell Statistics") was calculated. Since the infiltration rate can be considered as the most important soil characteristic to create direct runoff from rainfall event (primarily in planes), the resulting map of $\mathrm{CN}$ values (Fig. 2) was formed as the maximum CN value determined from HSG by infiltration and average values CN of HSG by all the used categorizations (tool "Cell Statistics"). This emphasized the influence of a low infiltration rate of soils in the flat area and influence of water retention capacity and the slope of the territory in areas with steeper terrain (Šercl, 2006).

For the calculations of direct runoff designed rainfall events with the annual exceedance probability of $\mathrm{p}=0.1 ; \mathrm{p}=0.02$ and $\mathrm{p}=0.01$ (return period of $\mathrm{N}=10, \mathrm{~N}=50$ and $\mathrm{N}=100$ years - i.e. 10-year, 50-year and 100-year rainfall) were used in this study. Calculation of the $\mathrm{N}$-year designed rainfall evenly distributed over the entire river basin area (assumption of CN method) were done by interpolation (spline method) in software ArcGIS 10.1 (tool "Spline" in 3D Analyst) of the Nyear rainfall in the rain gauge stations within the Otava river basin and its surroundings. The 24hour designed rainfall for each return period are as follows: $\mathrm{N} 10=82.6 \mathrm{~mm}, 112.2 \mathrm{~mm}=\mathrm{N} 50$ and $\mathrm{N} 100=125 \mathrm{~mm}$. 


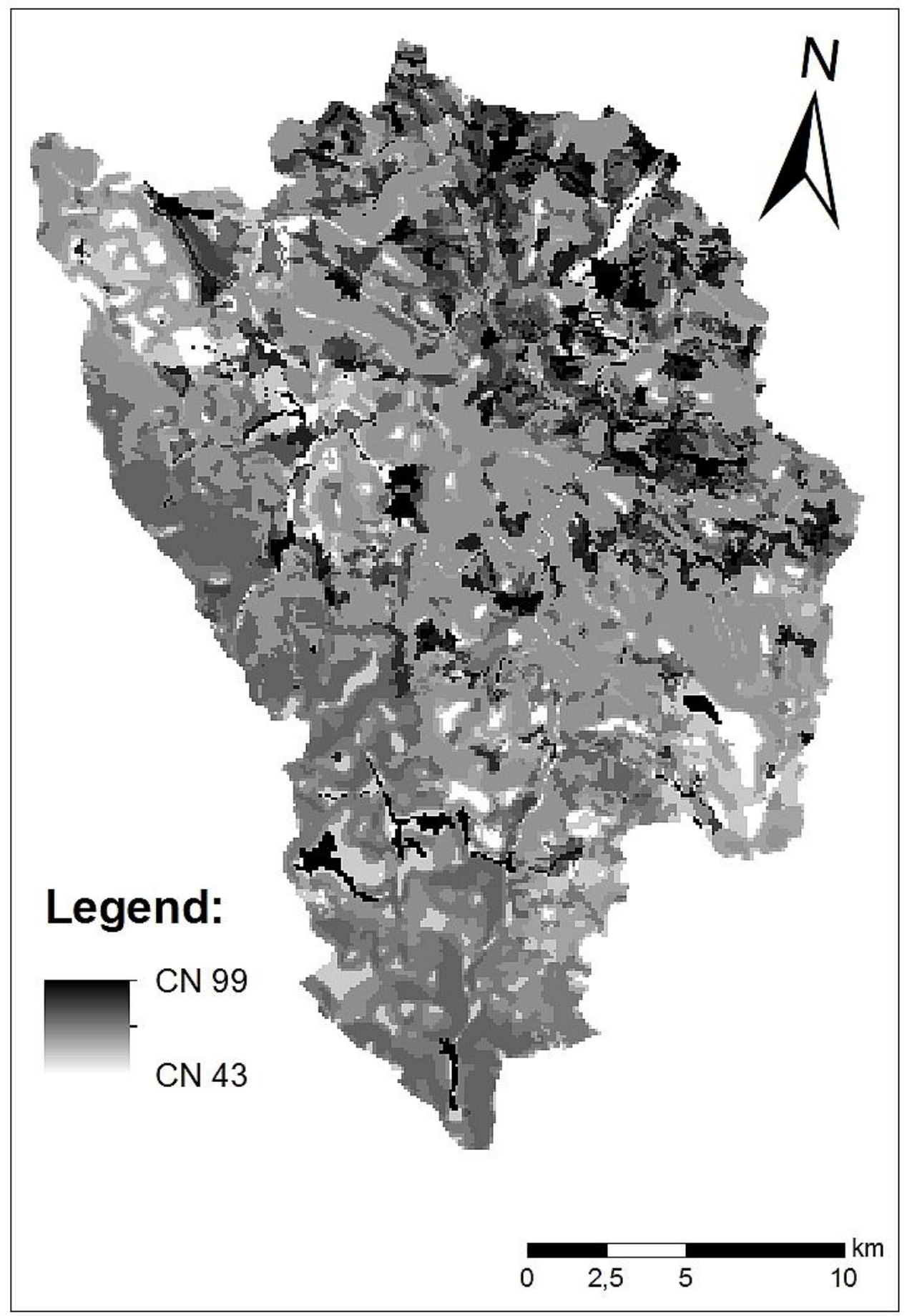

Fig 2. Example of the map of final CN values in the 2012.

The values of the direct runoff $(\mathrm{mm})$ and its volumes $\left(\mathrm{m}^{3}\right)$ for each input $\mathrm{CN}$ raster for the years 1970, 1990, 2000, 2006 and 2012, and for each designed rainfall events (10-year, 50-year and 100-year) were subsequently calculated (using the formulas given above by the GIS tool "Raster Calculator") in ArcGIS 10.1. Example of the resulting direct runoff volume raster in $\mathrm{m} 3$ calculated for the 10-year rainfall and land use in 2012 is on the Figure 3. 


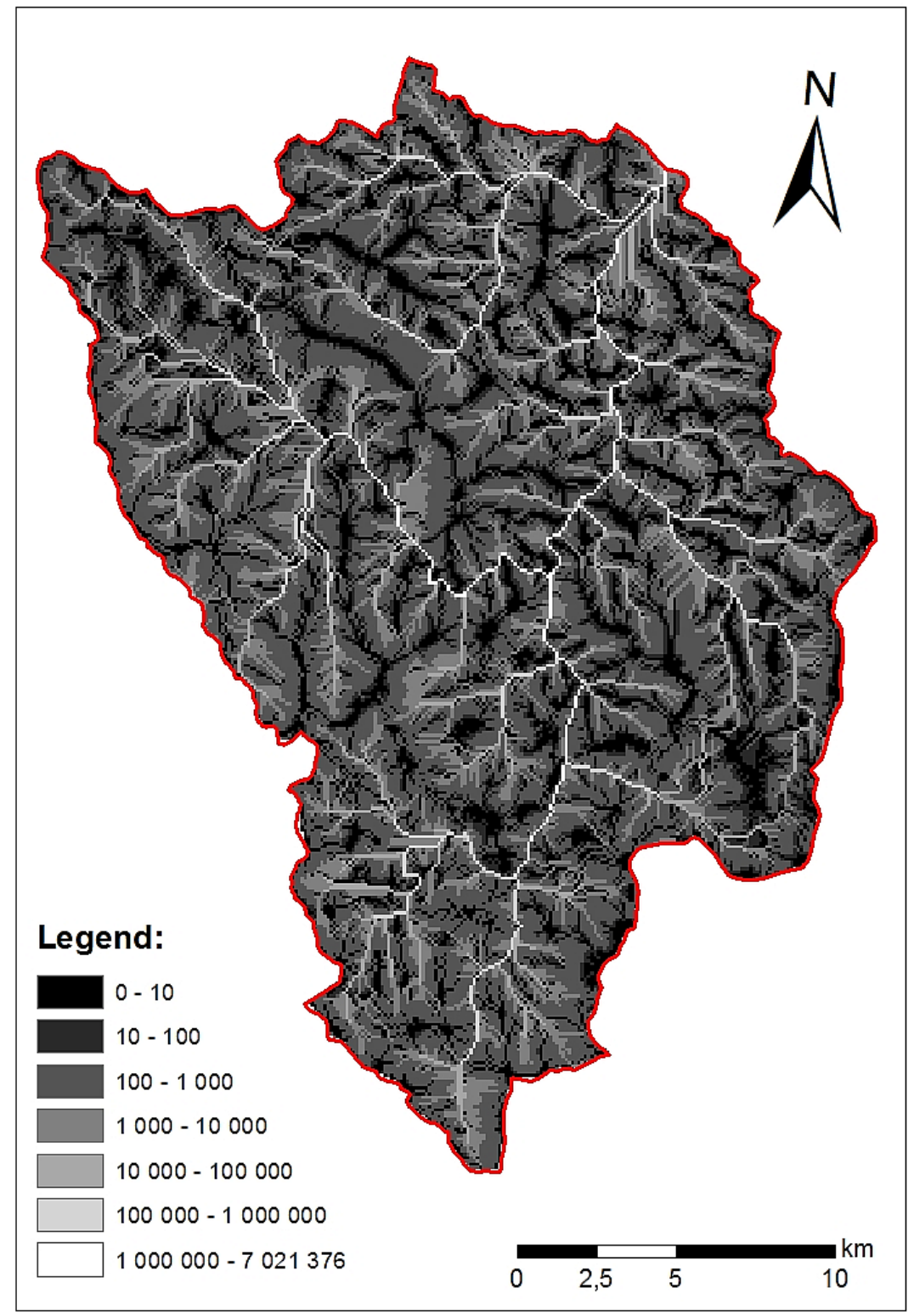

Fig 3. Direct runoff volume [m³] for 10-year rainfall in 2012.

\section{Results and discussion}

\subsection{Land use changes}

The subject area was under the observation period and often radically altered. the year 1970 , which represents the state before until the mid-18th century was selected as a reference datum. The whole area of Šumava mountains was predominantly forested, only small part of the mountainous part of the examined catchments was used as small scale fields and grassland. These parts were surrounding the small municipalities. Many of them was depopulated and destroyed after 1945 after German inhabitants were displaced to Germany. After that the territory stayed abandoned and the parts of fields were turned into grasslands or later into forests. These changes can be traced until 1970. It should be noted that since 1970 the use of territory has changed significantly nearly in the entire surface. The changes in the land use of the whole catchment are documented in the Figure 4 and 5. 


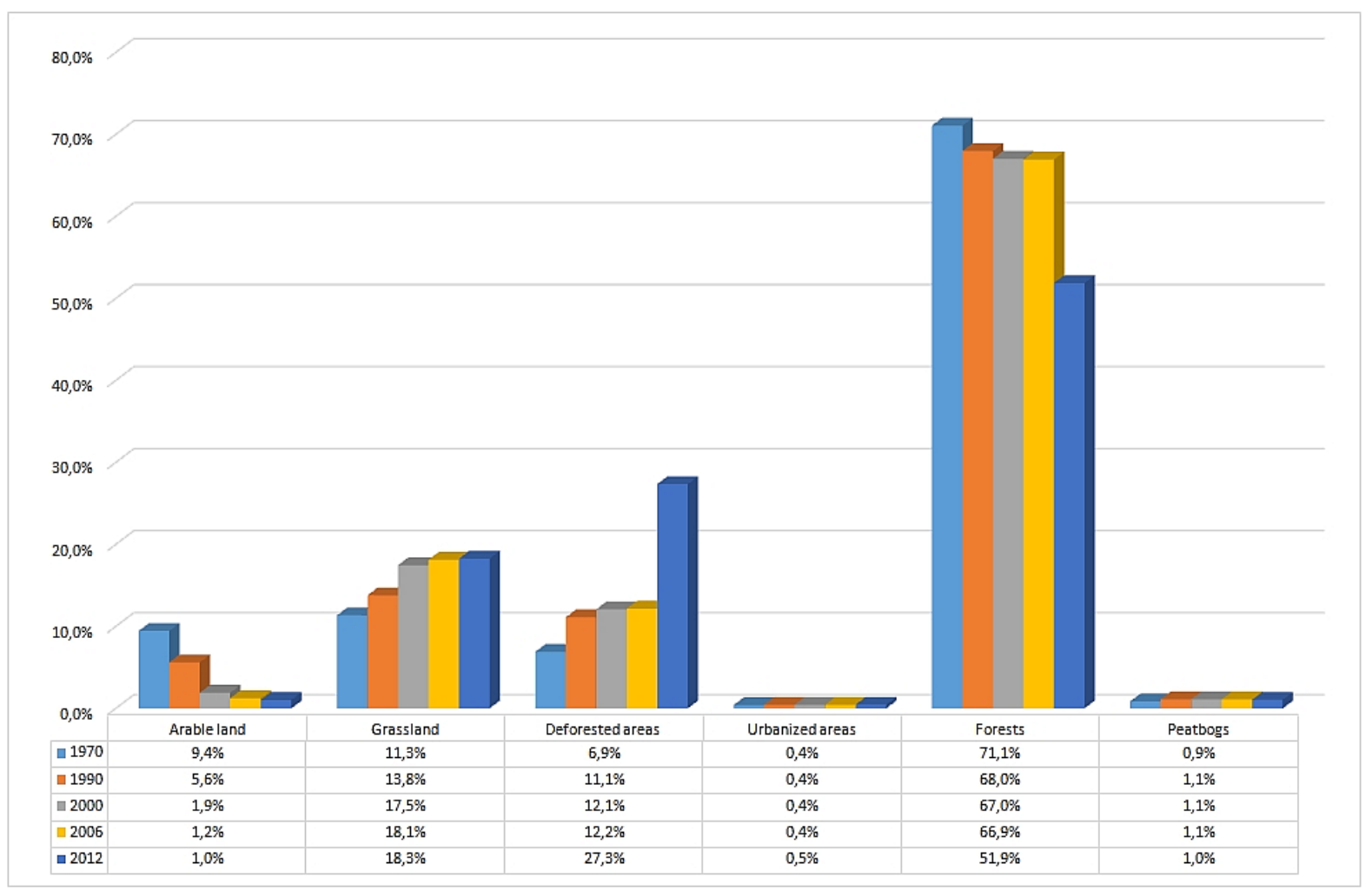

Fig 4. Changes of land use in the Otava catchment.

Changes are practically constant, and at two basic levels:

1) Conversion of arable land with varying intensity at different management of intensive and extensive grassland

2) Deforestation of large areas of indigenous mostly spruce monocultures and their transfer to the shrub and herbaceous vegetation covering the surface with a discontinuous vegetation

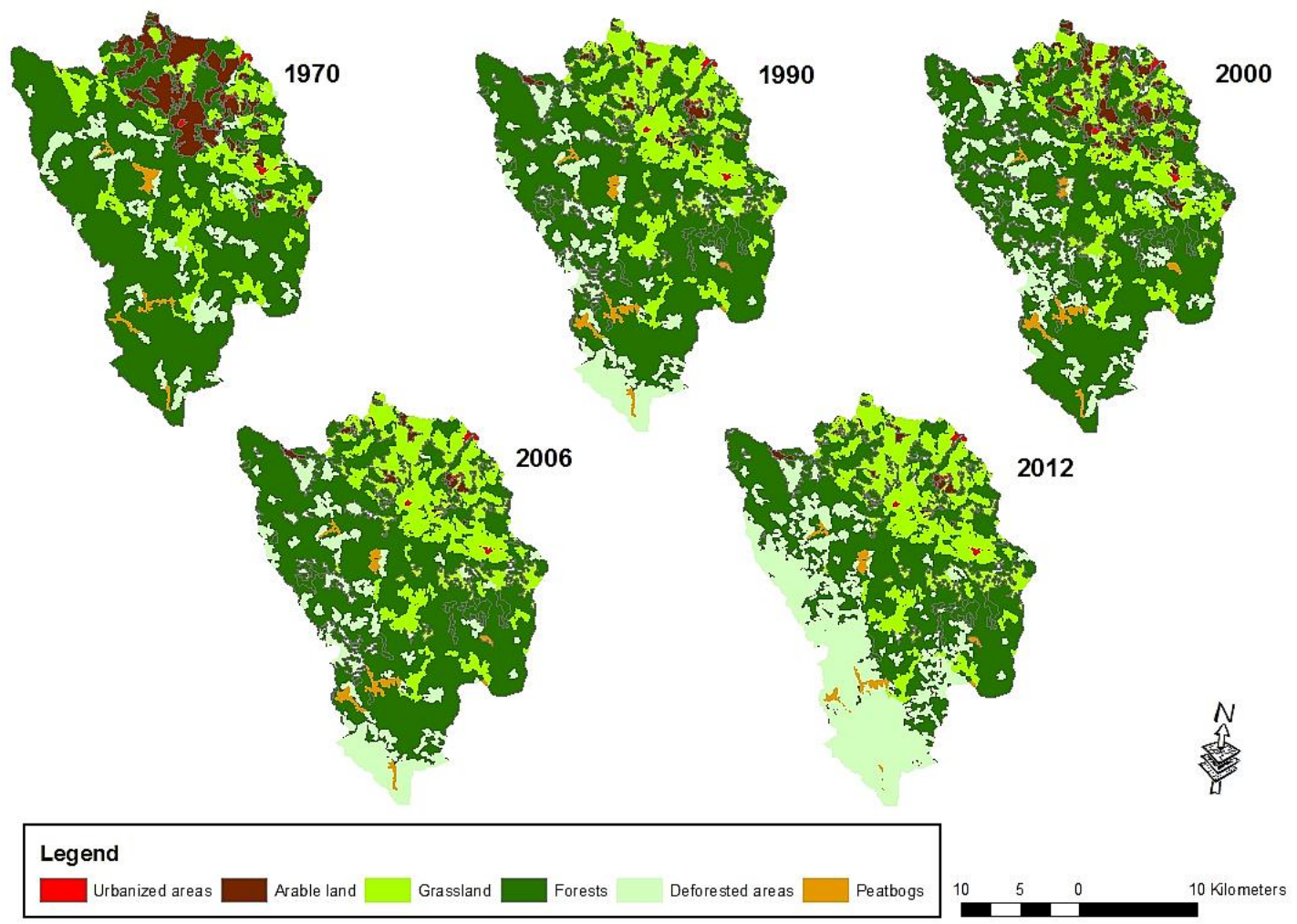

Fig 5. Changes of land use in the Otava catchment - spatial distribution of the land use categories. 
The first-mentioned change in the area is related to the transfer of arable land to various forms of permanent grassland. This change was caused mainly by economic as well as environmental reasons. The first significant change was recorded in 1990. The conversion of cropland to permanent grass cover was related to the change of the political situation in the whole Central and Eastern Europe. Under this pressure and under pressure from neighbouring countries and consequently the European Union, there have been some partial changes in land use (Sklenička, 1999). These changes were reflected off the site of interest, especially in the ongoing reduction in the percentage of arable land throughout the country in the period after 2004. This trend is supported by setting state and the European Union subsidy policy (Kouriilová, Pšenčík, Kopta, 2009). The main driving force that brought about changes in the conversion of cropland to permanent grass cover was the creation of agri-environment grant scheme. Conversion of arable land has continuing problems with degradation of arable land by erosion, compaction, etc. The measure is divided into six titles, because grassing can be made by three kinds of mixtures. Then there can be distinguished grassing of parts near water or in protective zones of water sources and grassing outside this area. Species-rich mixture is appearing for the first time and represent a certain alternative to tighter regional blends. The aid is effective and permanent protection of soil against erosion, water pollution prevention, increasing species diversity and attractiveness of the landscape. Changes in agricultural commodity markets also brought a reduction in livestock, particularly cattle for milk production. These breeds were either cancelled without refund or farmers switched to less intensive cattle breeding ongoing grazing manner. For this reason, there is a constant increase in the acreage of grassland at the expense of other categories of agricultural land (Csaki, Lerman, 1997).

The demonstrated changes in the land use are best shown in the Volšovka catchment as documented in the Figure 6 and 7.

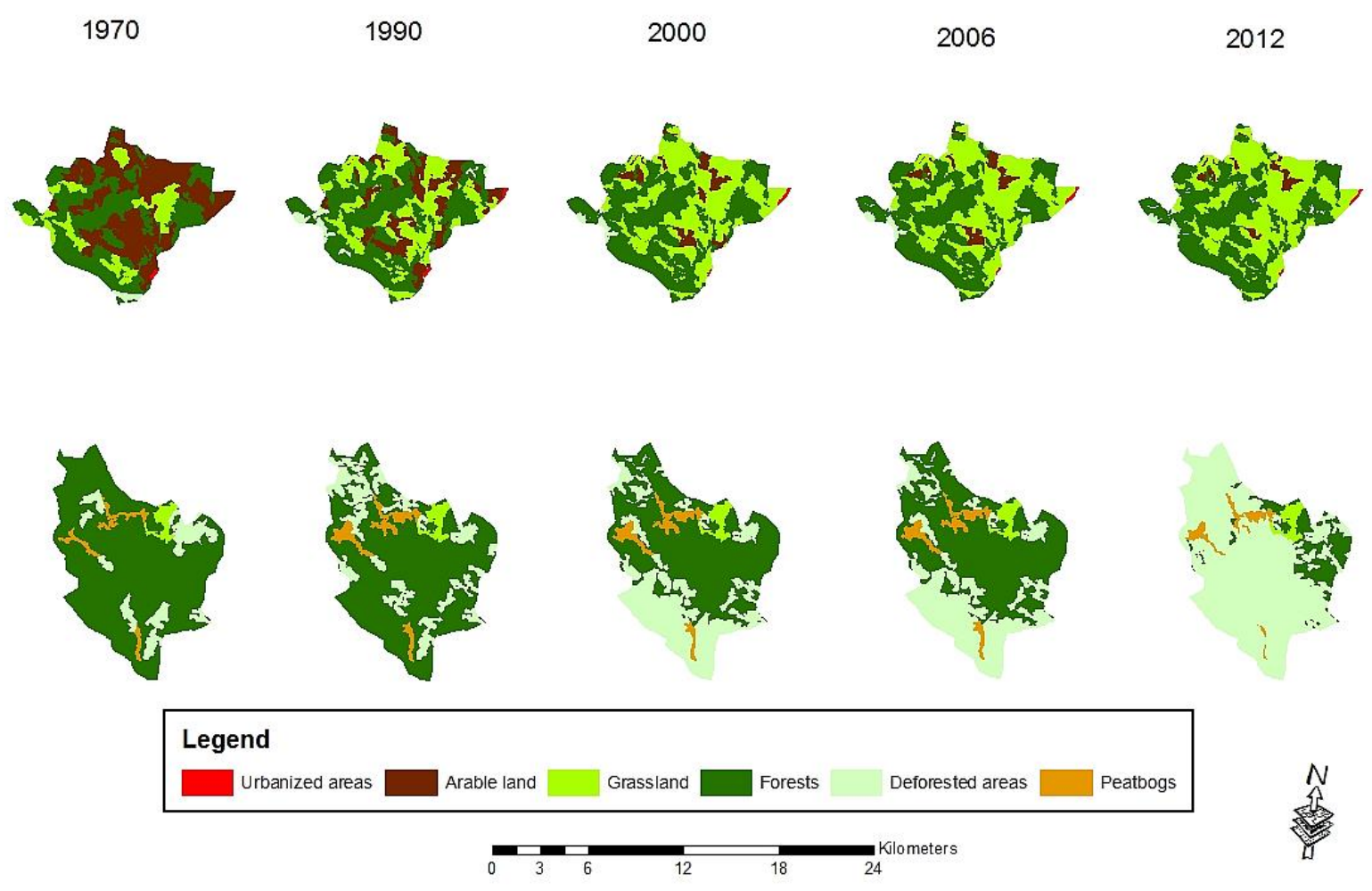

Fig 6. Changes of land use in the Volšovka and Vydra catchment - spatial distribution of the land use categories. 


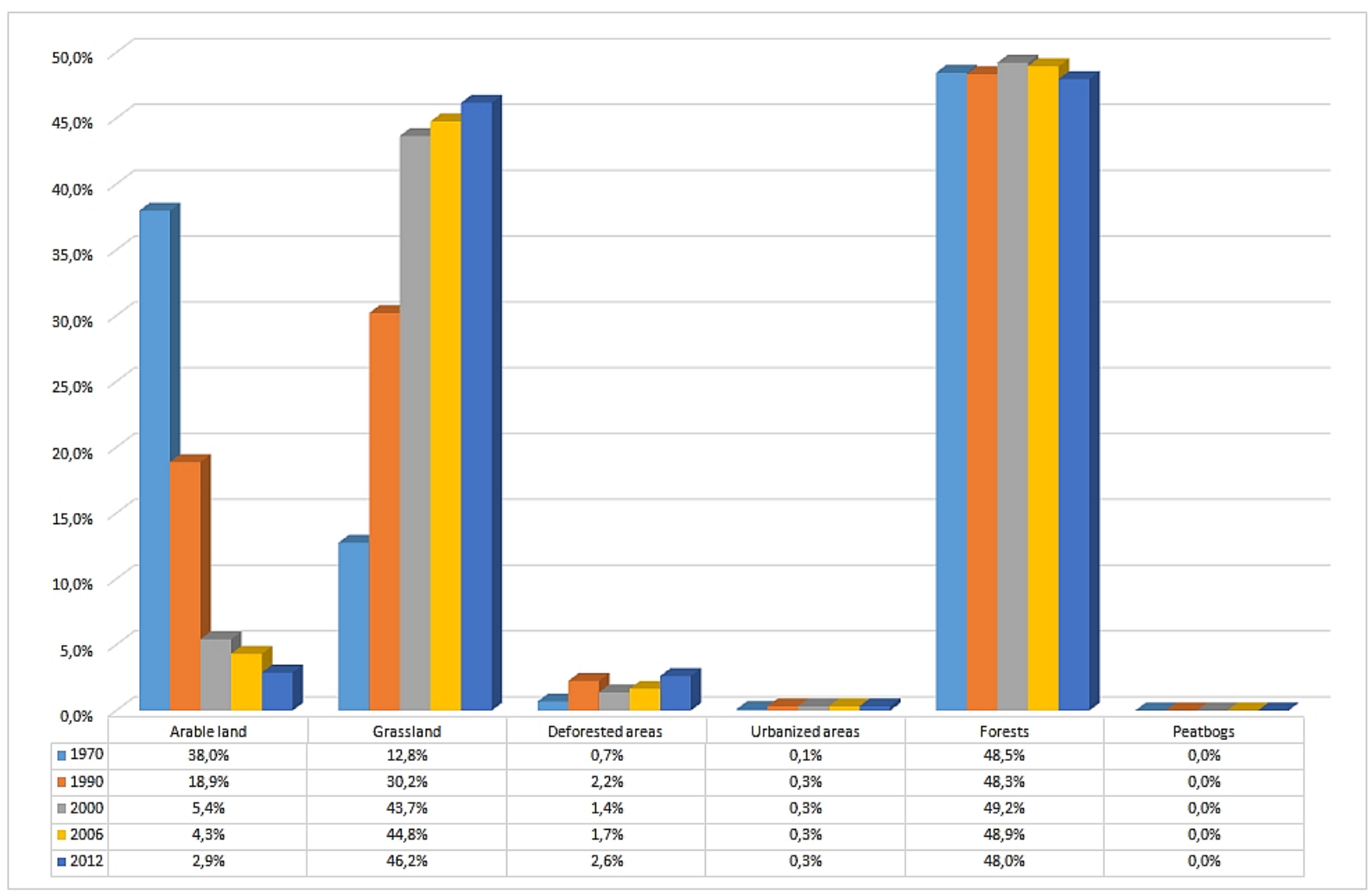

Fig 7. Changes of land use in the Volšovka catchment.

The second described change - loss of forest areas - was first recorded in 1990. It was a change to a smaller portion of the territory over the coming decades.

The cause must be sought in the past. During the 18th century, after the last big wave of settlement, there was a large loss of forest area. Due grazing in the forest and favouring mining hardwood species richness was negatively affected (Hrib et al., 2009). In addition to the clearcutting for the needs of glassworks and subsequent afforestation of even-aged spruce monocultures is causal primarily wind calamity of October 1870. After described natural disaster areas were promptly reforested by trees. Spruce seedlings were imported for this purpose from all parts of the former republic and their genetic composition differs from the original Šmava spruces (Mánek, 2001). This led to a weakening of natural populations of native spruce, that were already years adapted to local conditions. The result is often highly unstable growth with reduced resistance to diseases and pests like bark beetle (Fanta, 1997). Another negative influence for resilience of forests were caused by the discharge of pollutants and acid deposition into the atmosphere (Kopáček et al., 2009). Pollution took place from the beginning of the Industrial Revolution until the 80s of the 20th century. In our country, stronger steps against atmospheric pollution were taken after 1989. Because of these changes, the forest is weakened, decreasing vitality and substantially increases the risk of possible damage by disturbances (Fanta, 1997). The most significant disturbance on the area of interest is considered the influence of wind and insects (Jonášová, Prach, 2008). Based on historical sources the important fact is that a wind storm or gale in the past in the Bohemian occurred quite frequently, but their frequency varied over the centuries (Skuhravý, 2002; Dobrovolný, Brázdil, 2003). Currently, it is more frequent, but their appearance and in the future to be reckoned with frequent wind warps at high speeds (Kolejka et al., 2010).

The loss of forests between 1970 and 1990 has its cause in the first place outside the area of interest. During the years 1983 and 1984 the areas of neighbouring Bavarian National Park were affected by two powerful winds, which damaged large areas of valuable forest ecosystems in the first zone of the national park (Skuhravý, 2002; Jonášová, Prach, 2008). Heavily damaged forest in non-intervention part of the Bavarian National Park has become a breeding ground for the rapid development of the bark beetle, which subsequently began to spread into the surrounding forests. Czech part of Šumava was hit by bark beetle in 1990 (Skuhravý, 2002). 
Monocultural local spruce forest significantly contributed to the rapid development of the bark beetle in Sumava, which reduces the ability of spruce forests to withstand the stresses caused by strong winds (Jonášová, Prach, 2004).

Already so weakened and reduced stands of forest were damaged even more. The next big hit in the Šumava mountain spruce came on the night of 18 to 19 January 2007 when the Bohemian Forests caught wind of hurricane force, named Kyrill. The highest recorded wind force in national park was $176 \mathrm{~km} / \mathrm{h}$. Thus, strong winds caused extensive damage to forests in dozens of square kilometres (Kolejka et al., 2010). It fell victim to around one million cubic meters of wood.

Windstorm hit the most senior parts of the Šumava National Park. The subsequent massive loss of forested areas between 2006 and 2012 took care of warm and dry late winter and early spring, which caused a very rapid onset of bark beetles (Steyrer, Tomiczek, 2007).

A total of about 217.000 trees in the forests of the National Park Šmava left without treatment. Raw windbreaks have become a source of spread of spruce bark beetles in the area. Mining infested trees in 2010 exceeded historical maximum and reached the highest value in the history of the Šumava National Park. Even in forests left to spontaneous development was the death of hundreds of thousands of adult pines.

The demonstrated changes in the land use are best shown in the Vydra catchment as documented in the Fig. 7 and 8.

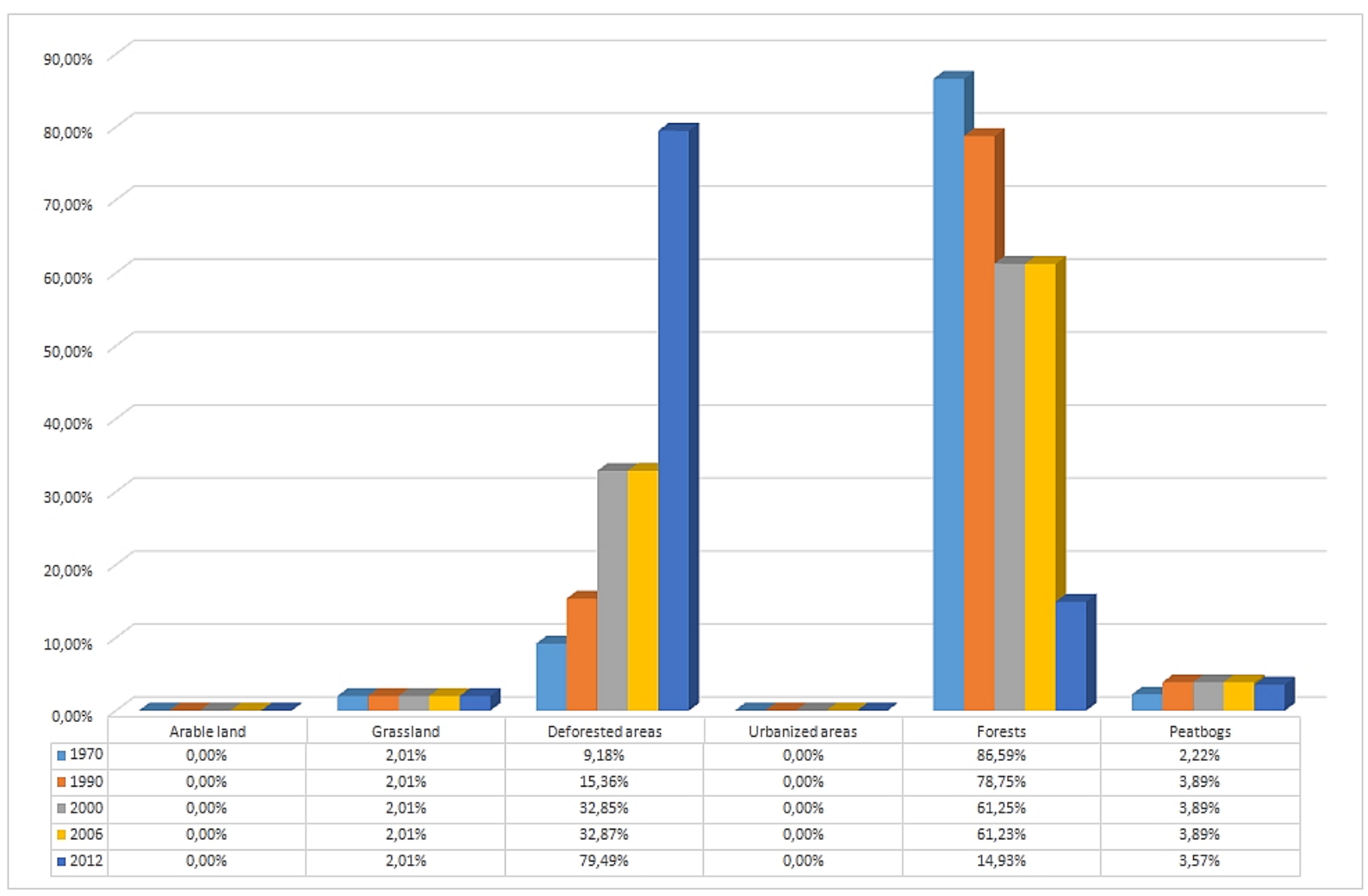

Fig 8. Changes of land use in the Vydra catchment. 


\subsection{Runoff characteristics}

The resulting values of the heights of direct runoff and runoff coefficients for individual designed rains are shown in Tables 1 and 2.

Tab 1. Direct runoff [mm] for designed rainfall with periodicity 10, 50 and 100 years on Otava river basin and its subcatchments (Volšovka and Vydra).

\begin{tabular}{|l|l|l|l|l|l|l|l|l|l|}
\hline \multirow{2}{*}{ Year / Designed ra infall } & \multicolumn{2}{l}{$\mathrm{l}$ N10 $(82.6 \mathrm{~mm})$} & \multicolumn{2}{l|}{$\mathrm{N} 50(111.2 \mathrm{~mm})$} & \multicolumn{2}{l|}{$\mathrm{N} 100(125.0 \mathrm{~mm})$} \\
\cline { 2 - 10 } & Otava & Volsovka & Vydra & Otava & Volsovka & Vydra & Otava & Volsovka & Vydra \\
\hline 2012 & 13,6 & 15,9 & 14,1 & 28 & 31,9 & 28,7 & 35,3 & 39,8 & 36,1 \\
2006 & 12,9 & 16,1 & 11,9 & 26,8 & 32,1 & 24,9 & 33,9 & 40 & 31,6 \\
2000 & 13 & 16,4 & 11,8 & 27 & 32,5 & 24,8 & 34,1 & 40,5 & 31,5 \\
1990 & 13,8 & 19,5 & 10,9 & 28 & 36,6 & 23,2 & 35,2 & 45 & 29,7 \\
1970 & 13,8 & 22,9 & 9,3 & 28 & 41,1 & 21 & 35,2 & 49,8 & 27,2 \\
\hline
\end{tabular}

The results suggest the influence of land use changes that have occurred in the river basins in the past, and the formation of runoff. However, differences in values of runoff are not remarkable in the Otava river basin. The highest differences were, based on model, between 2006 and 2012. In this period the large areas near the river basin borders were deforested due to combination of bark beetle calamity, windstorm and excavation of remnants of forest. This change (see Fig. 6 and Tab. 3) is clearly reflected in the Vydra subcatchments, where the value of direct runoff changed much more intensely between 2006 and 2012. In the Otava river basin, these changes (i.e. deforestation) have not such an impact due to scale effect (changes occurred in a relatively small area such a large basin) and mixed effect on the larger area - reduction of forest area counteract increase of grassland at the expense of arable land. The change is therefore evident, but not significant - by the hundred-year designed rainfall is the highest difference, which achieves in direct runoff height $1.4 \mathrm{~mm}$, in units of volume almost 750 thousand $\mathrm{m}^{3}$.

For other changes in land use of Otava river basin are differences in heights and volumes of runoff smaller, but even here it can be seen the positive impact of some changes. For example, reduction of direct runoff between 1990 and 2000 can be put into the context with the grassing of arable land after 1990. In contrast, surprisingly identical values of direct runoff model were calculated in 1970 and 1990, although there had been significant changes in the landscape. However, the loss of arable land, pasture and forest has been "offset" by the increase of meadows and bushes, so that was a mix of changes variously distributed across the river basin with almost no difference for creating direct runoff throughout the river basin.

These results confirm the findings of Kašpárek (2007), who based on the long-term observation and statistical analysis suggests that it is virtually impossible that changes in land use (if we exclude drastic interventions such as the permanent removal of vegetation cover from soil or the establishment of impervious surfaces) can permanently significantly change the long-term average height of runoff from the river basin. Similarly, Hanel et al. (2011) argue, that by larger basins whose area is in the hundreds $\mathrm{km}^{2}$ and which are not predominantly agriculturally used changing flood runoff volume and flow due to changes in land use is almost unreal. Because in this study there are modelled extreme precipitation events ( $N=10$ to $N=100$ years), the results also confirm the claim that the use of the land has only a marginal impact in the development of flash floods (Hattermann et al., 2012). Also, Hanel et al. (2011) adds that for flooding from extreme rainfall is the effect of land use on runoff volume and flow weaker compared with the importance of causal precipitation. This confirms Kašpárek and Krátká (2004), claiming that during the major floods in 2002 (which also took place at the catchments evaluated in this study), the influence of total rainfall on the height of the flood flow was completely dominant.

This conclusion does not mean that changes in land use and other measures decreasing surface runoff should be avoided. Changes in land use from arable land to grassland or forest naturally improves soil protection against erosion in the river basins and can have a significant impact on flood flow height and peak flow in smaller catchment area, especially for short-term floods. This 
is confirmed by results from subcatchments Volšovka (positive development for water retention) and Vydra (negative development for water retention). In Volšovka river basin is from 1970 continuously increasing the retention capacity of the landscape primarily by increased grassland instead of arable land. However, on the other hand in the Vydra river basin is continually increasing the value of direct runoff due to deforestation. This confirms Hornbeck et al. (1993) claiming that cutting down forests leads to a reduction of interception and evaporation, and consequently a larger share of the total rainfall is involved in surface runoff.

Žlábek (2009) find out by runoff time series analysis of several catchments that fully forested watershed has due to the high-water retention and evapotranspiration the lowest runoff coefficient. The runoff coefficient (15\%) was more than two or three times lower than in catchments with different land use (intensively farmed catchment with the village inside reach even 59\%). Similar conclusions mention Tallaksen (1993), Wegehenkel (2002) and Wegehenkel (2003). Likewise, Kovár (2006) and Bosch and Hewlett (1982) point at the high retention capacity of the forest by the least achieved maximum specific discharge in forest basins.

Despite the negative runoff characteristics development in Vydra river basin, the values of direct runoff calculated from the same design rainfall is still lower than in the basin Volšovka. In fact, in Vydra subcatchments forests were replaced by land cover, which can be characterized as a scrub and herb layer on the forest floor. $\mathrm{CN}$ value therefore varies, but the soil is permanently covered with vegetation and soil infiltration properties themselves remain at a good level.

Tab 2. Direct runoff coefficient [\%] for designed rainfall with periodicity 10, 50 and 100 years on Otava river basin and its subcatchments (Volšovka and Vydra).

\begin{tabular}{|l|l|l|l|l|l|l|l|l|l|}
\hline \multirow{2}{*}{ Year / Designed ra infall } & \multicolumn{3}{l}{ N10 $(82.6 \mathrm{~mm})$} & \multicolumn{2}{l|}{ N50 $(111.2 \mathrm{~mm})$} & \multicolumn{2}{l|}{ N100 $(125.0 \mathrm{~mm})$} \\
\cline { 2 - 10 } & Otava & Volsovka & Vydra & Otava & Volsovka & Vydra & Otava & Volsovka & Vydra \\
\hline 2012 & 16,5 & 19,2 & 17,1 & 25,0 & 28,7 & 25,8 & 28,2 & 31,8 & 28,9 \\
2006 & 15,6 & 19,5 & 14,4 & 23,9 & 28,9 & 22,4 & 27,1 & 32,0 & 25,3 \\
2000 & 15,7 & 19,9 & 14,3 & 24,1 & 29,2 & 22,3 & 27,3 & 32,4 & 25,2 \\
1990 & 16,7 & 23,6 & 13,2 & 25,0 & 32,9 & 20,9 & 28,2 & 36,0 & 23,8 \\
1970 & 16,7 & 27,7 & 11,3 & 25,0 & 37,0 & 18,9 & 28,2 & 39,8 & 21,8 \\
\hline
\end{tabular}

The above described changes are reflected in the characteristics expressed in relative terms (runoff coefficients - Tab. 2). Moreover, it is seen that the coefficients of runoff during designed rainfall $\mathrm{N}=10$ to $\mathrm{N}=100$ years are in the range of about $15-30 \%$ (except for Volšovka subcatchment). This confirms the findings of Kašpárek et al. (2010) that the runoff coefficients of flood flow even by a very intensive and large precipitation are close to the value of $30 \%$. Similar values are seen on the charts published by Kašpárek and Krátká (2004), which suggests that in exceptional floods in 2002 runoff coefficients were maximally to $30 \%$ in the river basin areas larger than $400 \mathrm{~km}^{2}$ with total rainfall amount varying from 80 to $150 \mathrm{~mm}$. Results from the Volšovka catchment show that the runoff coefficients can be higher than $30 \%$ after intense rainfall episode, especially for smaller catchments, which are predominantly agriculturally used.

The results were not compared with the measured data at the catchment outlet since the model entered designed rainfall events (theoretical - 10-year, 50-year and 100-year rainfall), not real rainfall totals. However, many authors consider the SCS-CN (Soil Conservation Service curve number) method as a one which yields satisfactory results (for example Schulze et al. (1992), Hawkins (1993), Bonta (1997), Zhan and Huang (2004), etc.). Shadeed and Almasri (2010) claim that the accuracy of the GIS-based SCS-CN method in estimating direct surface runoff is found to be about $85 \%$ (for the arid to semi-arid Palestinian catchments). This value is good enough to assume the applicability of the SCS-CN method in predicting runoff generation amounts.

\section{Conclusions}

Landscape in mountain and foothill areas of the Czech Republic has undergone over the last half century many changes that have a different impact on water retention and consequently runoff 
characteristics during intense rainfall. In mountainous areas (especially borderline top ridges areas) land use remained mostly relatively unchanged (i.e. almost completely forested), but in some areas (e.g. Vydra river basin), the runoff characteristics deteriorate due to the vulnerability of monoculture spruce forests by natural disasters (windstorms), diseases and pests. Conversely, in the foothill areas retention capacity is increasing due to conversion of arable land with varying intensity at different management of intensive or extensive meadows and pastures, especially after the year 1990.

\section{Acknowledgements}

This publication was created with the contribution of a grant of the University of Southern Bohemia in Ceske Budejovice 081/2016/Z The water in the cultural landscape in a period of climate change.

\section{References}

[1] Badoux, A., Jeisy, M., Kienholz, H., Lüscher, P., Weingartner, R., Witzig, J. \& Hegg, Ch. (2006). Influence of storm damage on the runoff generation in two sub-catchments of the Sperbelgraben, Swiss Emmental. European Journal of Forest Research 125(1), 27-41. DOI: 10.1007/s10342-005-0102-6.

[2] Bíba, M., Vícha, K., Janová, M. \& Jarabáč, M. (2010). Obnova lesa v experimentálním povodí Červík a její vliv na odtokový proces. Zprávy lesnického výzkumu 55(2), 126-132.

[3] Bonta, J. V. (1997). Determination of watershed curve number using derived distributions. Journal of Irrigation and Drainage Engineering, 123(1), 28-36. DOI: 10.1061/(ASCE)07339437(1997)123:1(28).

[4] Bosch, J. M. \& Hewlett, J. B. (1982). A review of catchment experiments to determine the effect of vegetation changes on water yield and evapotranspiration. Journal of Hydrology 55 (1-4), 3-23. DOI: 10.1016/0022-1694(82)90117-2.

[5] Csaki, C. \& Lerman, Z. (1997). Land in East Central Europe and CIS in the 1990s: Expectations and achievements after the first five years. European Review of Agricultural Economics 24(3-4), 428-452. DOI: 10.1093/erae/24.3-4.428.

[6] Dobrovolný, P. \& Brázdil, R. (2003). Documentary evidence on strong winds related to convective storms in the Czech Republic since AD 1500. Atmospheric Research, 67-68, 95116. DOI: 10.1016/S0169-8095(03)00046-2.

[7] Fanta, J. (1997). Rehabilitating degraded forest in Central Europe into self-sustaining forest ecosysrems. Ecological Engineering 8(4), 289-297. DOI: 10.1016/S0925-8574(97)00024-4.

[8] Hanel, M., Kašpárek, L., Mrkvičková, M., Horáček, S., Vezina, A., Novický, O. \& Fridrichová, R. (2011). Odhad dopadů klimatické změny na hydrologickou bilanci v ČR a možná adaptační opatření. Prague: T. G. Masaryk Research Institute of Water Management.

[9] Hattermann, F. F., Huang, S., Vetter, T., Kron, W., Burghoff, O., Merz, B., Bronstert, A., Krysanova, V., Gerstengarbe, F.-W., Werner, P. \& Hauf, Y. (2012). Flood Risk from a Holistic Perspective - Observed Changes in Germany. In: Kundzewitz, Z. W. (Ed.) Changes in Flood Risk in Europe (pp. 212-237). New York: IAHR Press.

[10] Hawkins, R. H. (1993). Asymptotic determination of runoff curve numbers from data. Journal of Irrigation and Drainage Engineering 119(2), 334-345. DOI: 10.1061/(ASCE)07339437(1993)119:2(334).

[11] Hornbeck, J. W., Adams, B. M., Corbett, E. S., Verry, E. S. \& Lynnch, P. J. (1993). Longterm impacts of forest treatment on water yield: a summary for northern USA. Journal of Hydrology, 150(2), 323-344. DOI: 10.1016/0022-1694(93)90115-P. 
[12] Hrib, M., Kopp, J., Křivánek, J., Kyzlík, P., Moucha, P., Němec, J., Oliva, J., Pelc, F., Pešková, V., Roček, I., Řezáč, J., Slabá, M., Vančura, K., Vašíček, J., Zahradník, P. \& Zatloukal, V. (2009). Lesy v České republice. Praha: Lesy ČR, Consult.

[13] Janeček, M. (2002). Ochrana zemědělské půdy před erozí. Prague: ISV nakladatelství.

[14] Janeček, M. \& Kovář, P. (2010). Aktuálnost „metody čísel odtokových křivek - CN“ k určování prímého odtoku z malých povodí. Vodní hospodářství 60(7), 187-190.

[15] Jonášová, M. \& Prach, K. (2004). Central-European mountain spruce (Picea abies (L) Karst.) forests: regeneration of tree species after a bark beetle outbreak. Ecological Engineering 23(1), 15-27. DOI: 10.1016/j.ecoleng.2004.06.010.

[16] Jonášová, M. \& Prach, K. (2008). The influence of bark beetles outbreak vs. Salvage logging on ground layer vegetation in Central European mountain spruce forests. Biological Conservation, 141(6), 1525-1535. DOI: 10.1016/j.biocon.2008.03.013.

[17] Kašpárek, L. (2007). Shrnutí poznatku o vlivu fyzicko-geografických charakteristik povodí na základní charakteristiky průtoku. In: Blažková, Š. (Ed.) Vybrané výsledky projektu Labe IV 2003-2006, Hydrologická tématika se zaměřením na retenci vody v povodí (pp. 52-64). Praha: The Czech Association of Scientific and Technical Societies.

[18] Kašpárek, L., Eckhardt, P. \& Hanel, M. (2010). Možnosti zmírnění současných důsledků klimatické změny zlepšením akumulační schopnosti v povodí Rakovnického potoka (pilotní projekt). Prague: T. G. Masaryk Research Institute of Water Management.

[19] Kašpárek, L. \& Krátká, M. (2004). Analýza vlivu fyzicko-geografických charakteristik na tvorbu povodňového odtoku a sestavení publikace o povodni 2002 [Research report]. Prague: T. G. Masaryk Research Institute of Water Management.

[20] Kašpárek, L. \& Peláková, M. (2014). Analýza citlivosti změn objemu př́ímého odtoku a infiltrace do pưdy při potenciálních změnách užívání pozemků. Vodní hospodářství 64(10), 8-12.

[21] Kolejka, J., Klimánek, M., Mikita, T. \& Svoboda, J. (2010). Polomy na Šumavě způsobené orkánem Kyrill a spoluúčast reliéfu na poškození lesa. Geomorphologia Slovaca et Bohemica 10(2), 16-28.

[22] Kopáček, J., Turek, J., Hejzlar, J. \& Šantrůček, H. (2009). Canopy leaching of nutrients and metals in mountain spruce forest. Atmospheric Environment 45(34), 5443-5453. DOI: 10.1016/j.atmosenv.2009.07.031.

[23] Kouřilová, J., Pšenčík, J. \& Kopta, D. (2009). Dotace v zemědělství z hlediska komplexního pohledu a s prihlédnutím k ekologickému zemědělství. Brno: CERM.

[24] Kovář, P. (2006). The extent of land use impact on water regime. Plant, Soil and Environment 52(6), 239-244.

[25] Mánek, J. (2001). Elektroforetická laboratoř NP Šumava, její role a výsledky při výzkumu genetické diverzity smrku ztepilého na Šumavě a v ČR. In Mánek, J., ed., Aktuality šumavského výzkumu (pp. 129-133). Vimperk.

[26] Nejadhashemi, A. P., Wardynski, B. J. \& Munoz, J. D. (2011). Evaluating the impacts of land use changes on hydrologic responses in the agricultural regions of Michigan and Wisconsin. Hydrology and Earth System Sciences Discussions 8(2), 3421-3468. DOI: 10.5194/hessd8-3421-2011.

[27] Romanowicz, R. J., Kulasová, A., Ředinová, J. \& Blažková, Š. D. (2012). Influence of afforestation on water regime in Jizera Catchments, Czech Republic. Acta Geophysica 60(4), 1120-1142. DOI: 10.2478/s11600-012-0046-4.

[28] Schulze, R. E., Schmidt, E. J. \& Smithers, J. C. (1992). SCS-SA User Manual PC Based SCS Design Flood Estimates for Small Catchments in Southern Africa. Pietermaritzburg: University of Natal. 
[29] Shadeed, S. \& Almasri, M. (2010). Application of GIS-based SCS-CN method in West Bank catchments, Palestine. Water Science and Engineering 3(1), 1-13. DOI: 10.3882/j.issn.1674-2370.2010.01.001.

[30] Sklenička, P. (1999). Agro-Ecological Zoning and Conversion of Czech Agriculture. The Land, 3(1), 1-20.

[31] Skuhravý, V. (2002). Lýkožrout smrkový (Ips typographus L.) a jeho kalamity. Praha: Agrospoj.

[32] Steyrer, G. \& Tomiczek, C. (2007). Orkanschäden und Witterung begünstigen Borkenkäfer. Forstschutz Aktuell 40, 3-5.

[33] Šercl, P. (2006). Metoda CN křivek - průběžná zpráva na ČHMÚ Praha - Rozvoj a testování modelovacího systému pro predikci povodňových odtoků $v$ malých povodích [Research report]. Praha: DHI Hydroinform and Czech Hydrometeorological Institute.

[34] Tallaksen, L. M. (1995). A review of baseflow recession analysis. Journal of Hydrology 165(1-4), 349-370. DOI: 10.1016/0022-1694(94)02540-R.

[35] Wegehenkel, M. (2003). Longterm evaluation of land use changes on catchment water balance- a case study from North East Germany. Physics and Chemistry of the Earth, Parts $A / B / C, 28(33-36), 1281-1290$. DOI: 10.1016/j.pce.2003.09.004.

[36] Wegehenkel, M. (2002). Longterm evaluation of the impact of afforestation of arable land on landscape water balance. In Holko, L. \& Miklánek, P., eds., Interdisciplinary approaches in small catchment hydrology (pp. 209-214). Paris: International Hydrological Programme UNESCO.

[37] Zhan, X. Y. \& Huang, M. L. (2004). ArcCN-Runoff: An ArcGIS tool for generating curve number and runoff maps. Environmental Modeling \& Software 19(10), 875-879. DOI: 10.1016/j.envsoft.2004.03.001.

[38] Žlábek, P. (2009). Landscape matrix set up and its influence on runoff components [PhD thesis]. České Budějovice: University of South Bohemia. 